\title{
Diagnostic accuracy of heart fatty acid binding protein (H-FABP) and glycogen phosphorylase isoenzyme BB (GPBB) in diagnosis of acute myocardial infarction in patients with acute coronary syndrome
}

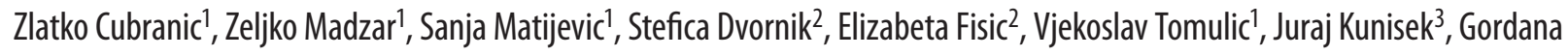 \\ Laskarin $^{4}$, Igor Kardum ${ }^{5}$, Luka Zaputovic ${ }^{*}$ \\ ${ }^{1}$ Department of Cardiovascular Medicine, University Hospital Rijeka, Rijeka, Croatia \\ 2 Department of Clinical Laboratory Diagnostics, University Hospital Rijeka, Rijeka, Croatia \\ ${ }^{3}$ Special Hospital Thalassotherapia Crikvenica, Crikvenica, Croatia \\ ${ }^{4}$ Division of Cardiology, Special hospital for medical rehabilitation of the hearth and lung diseases and rheumatism "Thalassotherapia \\ - Opatija", Opatija, Croatia and Department of Physiology and Immunology, Medical Faculty, University of Rijeka, Rijeka, Croatia \\ ${ }^{5}$ Department of Psychology, Faculty of Arts and Sciences, University of Rijeka, Rijeka, Croatia
}

*Corresponding author: lukaz@medri.hr

\begin{abstract}
Introduction: This study aimed to assess whether heart fatty acid-binding protein (H-FABP) and glycogen phosphorylase isoenzyme BB (GPBB) could be used for the accurate diagnosis of acute myocardial infarction (AMI) in acute coronary syndrome (ACS) patients.

Materials and methods: The study included $108 \mathrm{ACS}$ patients admitted to a coronary unit within $3 \mathrm{~h}$ after chest pain onset. AMI was distinguished from unstable angina (UA) using a classical cardiac troponin I (CTnl) assay. H-FABP and GPBB were measured by ELISA on admission (0 h) and at 3, 6, 12, and $24 \mathrm{~h}$ after admission; their accuracy to diagnose AMI was assessed using statistical methods.

Results: From 92 patients with ACS; 71 had AMI. H-FABP and GPBB had higher peak value after $3 \mathrm{~h}$ from admission than cTnl (P=0.001). Both markers normalized at $24 \mathrm{~h}$. The area under the receiver operating characteristic curves was significantly greater for both markers in AMI patients than in UA patients at all time points tested, including admission ( $\mathrm{P}<0.001)$. At admission, the H-FABP $(37 \%)$ and GPBB $(40 \%)$ sensitivities were relatively low. They increased at 3 and $6 \mathrm{~h}$ after admission for both markers and decreased again after $24 \mathrm{~h}$. It was $40 \%$ for H-FABP and approximately 2-times lower for GPBB ( $\mathrm{P}<0.01)$. In AMI patients, both biomarkers had similar specificities, positive- and negative-predictive values, positive and negative likelihood ratios, and risk ratios for AIM.
\end{abstract}

Conclusion: H-FABP and GPBB can contribute to early AMI diagnosis and can distinguish AMl from UA.

Key words: biological markers; heart fatty acid-binding protein; glycogen phosphorylase; sensitivity; specificity; acute myocardial infarction

\section{Introduction}

In interventional cardiology with stent revascularization, which localizes myocardial necrosis and decreases the possibility for ischaemic bias, it is very important to have reliable early biomarkers of myocardial cell injury. As a diagnostic tool, biomarkers could enable appropriate risk stratification for the increasing number of patients admitted to hospital with acute coronary syndrome (ACS) (1). It is accepted that acute myocardial infarction (AMI) refers to the death of cardiac myo- cytes because of prolonged ischemia that is in contrast to unstable angina (UA) in which the necrosis of cardiomyocytes does not occur (1-3). The routine introduction of cardiac troponins in the laboratory has radically improved the diagnosis of AMI, because only necrotic cardiomyocytes release these proteins into the blood $(1,2)$. Troponins are more specific and sensitive than the traditional cardiac enzymes, such as creatine kinase (CK) and its isoenzyme MB (CK-MB) and myoglobin (4). How- 
ever, cardiac troponin I (cTnl) can only be detected at least 4-6 h after AMI onset; moreover, its levels do not peak until 12 hours after onset (detected using classical cTnl enzyme linked immunoassays) (5). Consecutive cTnl measurements in combination with the use of reference change value represent a more sensitive tool for AMI detection and allow the evaluation of AMI at low troponin concentrations (6). There is no basic difference between cTnl and cardiac troponin T (cTnT) with respect to their ability to diagnose AMl; differences most frequently arise from variations in inclusion criteria, sampling patterns, or from the use of assays with different diagnostic cut-offs (1). At $2 \mathrm{~h}$ after AMI presentation, high-sensitivity cTnT assays are better diagnostic tools than cTnl assays (7). In addition, cTnT assay has a better prognostic ability than a conventional assay (7). However, the cTnT assay probably reflects early cTnT release from an increasingly permeable myocardial cell membrane rather than from a clinically threatening AMI (8). Thus high-sensitivity cTnT assay is probably not suitable for distinguishing AMI from UA.

During the last 20 years, many scientific groups have been searching for diagnostic biomarkers other than troponins that can predict ischemic myocardial injury (3,4,9-17). Of these, interleukin-6, high-sensitivity C-reactive protein and brain natriuretic peptide have been extensively validated and routinely used $(1,3)$. Heart fatty acid-binding protein (H-FABP) $(3,4,10-13)$ and glycogen phosphorylase isoenzyme BB (GPBB) (14-16) belong to a group of novel biomarkers. H-FABP is a $14.5 \mathrm{kDa}$, small, cytosolic protein that is abundant in the cytoplasm of cardiomyocytes, but is present in low concentrations in the blood and in tissues other than the heart (11). It appears in the blood as early as $1.5 \mathrm{~h}$ after $\mathrm{AMI}$ onset, peaks at approximately 6 $h$, and returns to baseline values within $24 \mathrm{~h}$ (11). However, its significance for the diagnosis and prognosis of AMI must be verified in future studies before it can be routinely used. Early biomarker studies have shown that GPBB is a very sensitive cardiac biomarker for early myocardial necrotic cell injury, as well as for ischaemia $(15,16)$. GPBB activation in myocardial ischaemia occurs as a result of an increase in glycogen degradation, which releas- es GPBB into the bloodstream (16). Its possible ability to discriminate myocardial necrosis from ischemia without necrosis is of a major clinical interest (1). However, there is still an emerging need for earlier and sufficiently specific cardiac biomarkers for ACS diagnosis $(3,8,14)$, with ability to distinguish AMI and UA.

The aim of this study was to assess the diagnostic accuracy of H-FABP and GPBB in ruling-in the acute myocardial infarction in patients with acute coronary syndrome, who were admitted to coronary unit within 3 hours after the chest pain.

\section{Materials and methods}

\section{Patients}

Between January and September 2011, we have enrolled a consecutive series of patients with chest pain in this cross-sectional study. From total number of patient, the patients having chest pain for longer than 3 hours, having chest pain non-suggestive for ACS, patients who died within 24 hours after the admission, patients who were inappropriately sampled or refused to participate in the study were excluded from the further investigation. Inclusion criteria for ACS were based on the European Society of Cardiology (ESC) guidelines on ACS, with patients requiring 2 out of 3 parameters for the diagnosis of AMI (suggestive coronary chest pain, electrocardiogram [ECG] changes, and a positive cTnl value) (1). In patients with suggestive coronary chest pain with duration $\geq 20$ minutes and/or ECG changes (new ST elevation at the J-point in two contiguous leads with the cut-off points: $\geq 0.2 \mathrm{mV}$ in men or $\geq 0.15 \mathrm{mV}$ in women in leads $\mathrm{V}_{2}-\mathrm{V}_{3}$ and/or $\geq 0.1 \mathrm{mV}$ in other leads, new horizontal or down-sloping ST depression $\geq 0.05$ $\mathrm{mV}$ in two contiguous leads; and/or T inversion $\geq$ $0.1 \mathrm{mV}$ in two contiguous leads with prominent Rwave or $\mathrm{R} / \mathrm{S}$ ratio $>1$ ). AMI was diagnosed by detecting the increase and/or decrease in cTnl values with at least 1 value above the 99th percentile of the upper reference limit $(0.2 \mu \mathrm{g} / \mathrm{L})$ (1). Patients with negative $c T n l$ values were diagnosed as having UA. All ACS patients (AMI and UA), admitted within $3 \mathrm{~h}$ from the onset of coronary chest pain to 
the Coronary Care Unit (CCU) of the Department for Internal medicine, University Hospital Rijeka, were examined further. Exclusion criteria were congenital heart disease, primary cardiomyopathy, pre-excitation syndrome, an implanted pacemaker or cardioverter defibrillator, acute infection, significant renal impairment (estimated glomerular filtration rate $[\mathrm{eGF}]<60 \mathrm{~mL} / \mathrm{min} / 1.73 \mathrm{~m}^{2}$ or autoimmune diseases, and reproductive period in women. Patients were classified as 'smokers' if they had smoked more than 10 cigarettes per day for $>1$ year during the last 2 years. Arterial hypertension was diagnosed if blood pressure was $>140 / 90$ $\mathrm{mmHg}$. Hyperlipidaemia was defined as total cholesterol concentration $>5 \mathrm{mmol} / \mathrm{L}$, low-density lipoprotein $(\mathrm{LDL})$ cholesterol levels $>3 \mathrm{mmol} / \mathrm{L}$, very-LDL levels $>1.7 \mathrm{mmol} / \mathrm{L}$, and high-density lipoprotein cholesterol levels of $<1.30 \mathrm{mmol} / \mathrm{L}$ for women and $<1.03 \mathrm{mmol} / \mathrm{L}$ for men (18). Diabetes mellitus was defined as fasting blood glucose level of $>7.1 \mathrm{mmol} / \mathrm{L}$ (19). The study protocol conformed to the ethical guidelines of the 1975 Declaration of Helsinki as reflected in a priori approval by the institution's Human Research Committee. All participants provided informed consent before participating in the study.

\section{Methods}

\section{Medical examination and patient treatments}

During anamnesis and the first medical examination on admission, age, gender, coronary risk factors including current blood pressure, previous heart disease (AMI, percutaneous coronary intervention, or $(A B G)$, and pain initiation-to-admission time were examined for each patient. A standard 12-lead ECG was taken on admission and at 12 and $24 \mathrm{~h}$ after the onset of the acute coronary event. Patients were followed up in the CCU during the entire investigation. Patients with ACS were treated according to European guidelines, which were relatively similar for all the patients. The treatment regimen included a $\beta$-blocking agent, an angiotensin-converting enzyme inhibitor, statin, and acetylsalicylic acid in accordance with the current European Heart Association guidelines (1).

\section{Blood sampling}

To estimate cTnl, H-FABP and GPBB concentrations, blood samples were collected from each patient at admission ("0-h" time point) and after 3, 6, 12, and $24 \mathrm{~h}$. To determine GPBB concentrations, $3 \mathrm{~mL}$ of peripheral blood was collected at each time point in a heparinised vacutainer (Becton Dickinson, Plymouth, UK). Within 30 min after collection, the samples were centrifuged at $3000 \times \mathrm{g}$ for 10 min, and plasma was immediately separated and frozen at $-20^{\circ} \mathrm{C}$. H-FABP and $\mathrm{cTnl}$ concentrations in serum samples were determined by collecting 3 $\mathrm{mL}$ of blood at the same time points as those for GPBB quantification. However, these samples were collected in vacutainers without an anticoagulant. Blood samples were left to clot for 30 min before centrifugation at $3000 \times \mathrm{g}$ for $10 \mathrm{~min}$. cTnl was assessed immediately from the serum; the remaining homogenate was aliquoted and frozen immediately at $-20^{\circ} \mathrm{C}$ for $\mathrm{H}$-FABP testing. All samples (10/ patient) were kept frozen for not more than 6 months before being tested. Repeated freezing and thawing cycles were avoided, and samples were tested by ELISA within 1 hour after thawing without further dilution. An additional blood sample $(3 \mathrm{~mL})$ was used to analyse glucose and lipid concentrations at the time of admission.

\section{Determination of biomarkers}

First, patients underwent serial testing with a conventional cTnl assay. The concentrations of cTnl in serum samples were analyzed immediately after centrifugation on the Dimension RxL (Siemens Healthcare Diagnostics, Newark, NJ, USA) by using reagents manufactured by the same company (Dimension Clinical Chemistry System, Heterogeneous Immunoassay Module, and Flex Reagent Cartridge). The detection range was between 0.04 and $40.00 \mathrm{ng} / \mathrm{mL}$, with intra-assay coefficient of variation $(\mathrm{CV})<6.85 \%$ and inter-assay CV of $<10 \%$ and a cut-off value of $0.2 \mathrm{ng} / \mathrm{mL}$ (CV < 10\%) (20). $\mathrm{H}-\mathrm{FABP}$ concentrations were determined by an ELISA test (Hycult Biotechnology, Uden, The Netherlands), with the upper limit of the reference range of $5.0 \mathrm{ng} / \mathrm{mL}$. The detection range was between 0.1 and $25.0 \mathrm{ng} / \mathrm{mL}$ (21). The GPBB concentrations were determined using the Diacordon 
GPBB-ELISA test (Diagenics, Dusseldorf, Germany), with the upper limit of the reference range of 7.0 $\mathrm{ng} / \mathrm{mL}(21,22)$. According to manufacturer, the detection range was between 3 and $100 \mathrm{ng} / \mathrm{mL}$, with intra-assay CV of $<6.85 \%$ and inter-assay imprecision CV of $<10.3 \mathrm{ng} / \mathrm{mL}$. The absorbencies of both, H-FABP- and GPBB-ELISA tests were measured using the Microplate reader MRX (Dynex Technologies, Denkendorf, Germany). All the tests were performed in the Department of Laboratory Diagnostic, University Hospital Rijeka, Rijeka, Croatia. The readers of the tests and reference standards were highly professionally educated persons, who were blind for the results of the other test.

\section{Statistical analysis}

Data analyses were performed using the SPSS 15.0 statistical package for Windows, Version SPSS Inc. 2006. (Chicago, IL, USA). The concentrations of $\mathrm{H}$ FABP, GPBB, and cTnl deviated significantly from normal distributions $(P<0.05)$ when measured by Kolmogorov-Smirnov tests (part of SPSS 15.0 statistical package) for patients in both the AMI and UA groups in each particular time point tested. Therefore, non-parametric tests were used for further evaluation of data. A non-parametric MannWhitney $U$ test was used to determine the difference between the 2 groups. A P-value of $<0.05$ was considered statistically significant. The chisquare test was performed for the categorical variables, with 2-tailed P-values of $<0.05$ regarded as significant. Continuous variables were presented as medians and 25th-75th percentiles, and categorical variables were presented as percentages. The receiver operating characteristic (ROC) curves were generated for each enzyme to assess the ability of each biomarker to be used as an early indicator of AMI. The area under the ROC curve (AUC) was calculated with 95\% confidence interval (CI). Sensitivities, specificities, positive- and negative-predictive values, positive and negative likelihood ratios, and risk ratios for AMI were calculated for each biomarker to determine its potential to diagnose AMI. Risk ratio was calculated from equation $R R=(a /(a+b) /(c /(c+d))$, where "a" represents really positive, „b" represents falsely positive, ${ }_{1} \mathrm{C}$ " represents falsely negative and ${ }_{\text { }} \mathrm{d}$ " represents really negative. A Z-test was used to compare the sensitivity and specificity of H-FABP with GPBB. Differences in concentrations between the individual markers were tested by Wilcoxon test. A relative increase was expressed as percentage of change from the initial state ( 0 - $h$ time point). The value obtained by the subtraction of 0 -h concentration from the concentrations at 3,6, 12, or $24 \mathrm{~h}$ was divided by the value at 0 -h time point and then multiplied by 100 . The power of study was calculated on the basis of cTnl values obtained in patients with AIM and UA. It accounts 0.845 or $84.5 \%$, what was acceptable, due to desired statistic power $>80 \%$. The power study was calculated using PS Power and Sample size Calculations, Version 3.0, January 2009, according the reference (23).

\section{Results}

\section{Patient characteristics}

Out of the 214 patients admitted to the CCU with chest pain, 122 patients were excluded from the study after anamnesis and physical examination (Figure 1). Patients who had experienced chest pain for more than $3 \mathrm{~h}$ at admission $(\mathrm{N}=108)$ were excluded from the study. Of the patients who experienced chest pain for less than $3 \mathrm{~h}$ at the admission, 14 were excluded from the study because of non-suggestive coronary chest pain $(\mathrm{N}=7)$, refusal to participate $(\mathrm{N}=1)$, death within $24 \mathrm{~h}(\mathrm{~N}=3)$, inappropriate blood sampling $(\mathrm{N}=3)$ (Figure 1). Patients with a suggestive coronary chest pain within less than $3 \mathrm{~h}$ before admission $(\mathrm{N}=94)$ were included in the study and cardiac markers were assessed. Patients with outlier concentrations of cardiac biomarkers $(\mathrm{N}=2)$ were also excluded from the study.

The median time from symptom onset to presentation was 2 (1.5-2.5) hours for AMI group and 2 (1.6-2.6) hours for UA group (Table 1). Patients were divided into 2 groups on admission: patients with AMI and positive cTnl level $(\mathrm{N}=71)$ and patients with UA and negative cTnl level $(N=21)$, which were determined from ECGs and CTnl concentrations (Figure 1). Beside cTnl, in both groups H-FABP and GPBB were assessed at the admission. 


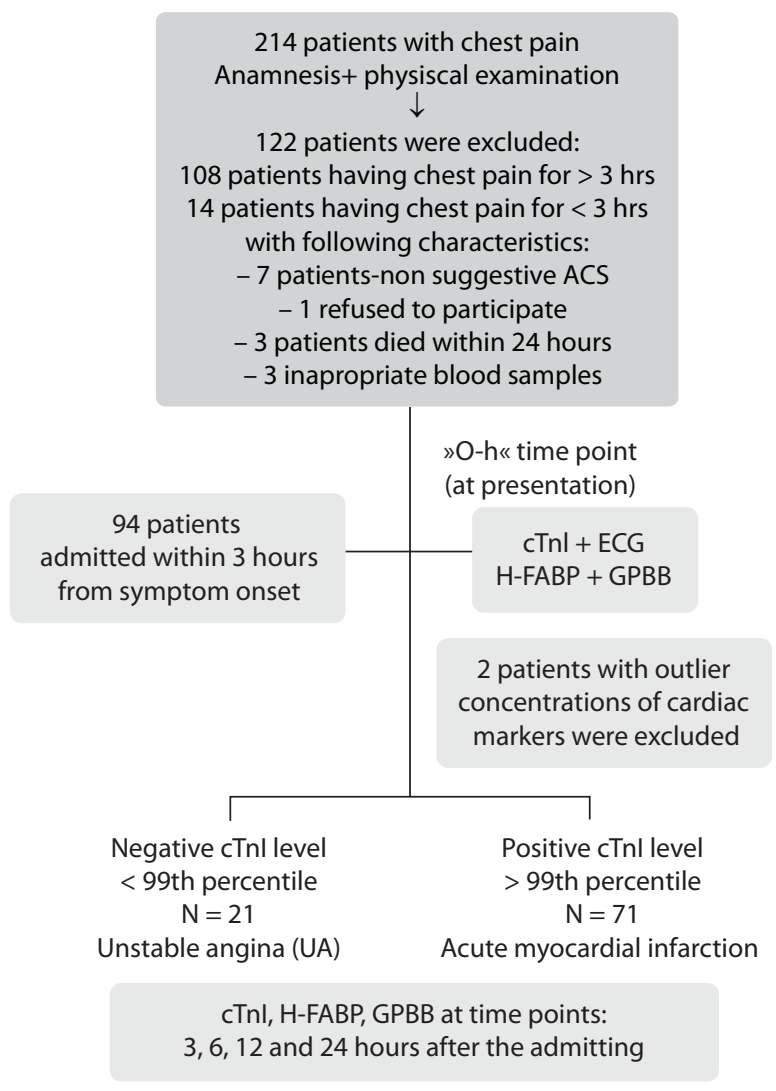

Figure 1. Recruitment of patients presenting with chest pain and results of early measurement of cTnl.
The groups did not significantly differ in age, sex and pain-to-admission time (Table 1). In the group of UA, hypertension was found in $90.5 \%$ of patients, what was significantly higher when compared to the AMI group (62\%, P = 0.028), whereas other risk factors such as smoking status, hyperlipidemia and diabetes mellitus did not differ significantly (Table 1). Previous myocardial infarction was more common in patients with UA then in patients with $\mathrm{AMI}(42.90 \%$ vs. $12.70 \% ; \mathrm{P}=0.006)$, whereas both groups of patients had similar percentage of percutaneous coronary intervention or coronary artery bypass grafting (Table 1).

\section{Cardiac biomarker dynamics}

Figure 2 shows cardiac biomarkers concentration dynamics and their interaction during the first 24 $\mathrm{h}$ after admission in patients with AMI. At the 0-h time point (within $3 \mathrm{~h}$ from the onset of $\mathrm{AMI}$ ), the concentrations of H-FABP and GPBB were similar and relatively low $(P(a)=0.254$, Figure $2 A$ and Figure 2, Table B); however, the levels of both biomarkers were higher than those of $\operatorname{cTnl}(P(b)$ and (c) $=0.001$, Figure 2, Table B). In the Figure 2, Table

TABLE 1. Characteristics of the whole group of patients enrolled in the study and the particular characteristics of patients with acute myocardial infarction and patients with unstable angina.

\begin{tabular}{|c|c|c|c|c|}
\hline & $\begin{array}{l}\text { All patients } \\
\mathrm{N}=92\end{array}$ & $\begin{array}{c}\text { AMI } \\
N=71\end{array}$ & $\begin{array}{c}\text { UA } \\
N=21\end{array}$ & $\mathbf{P}$ \\
\hline Age (years) & $62(28-89)$ & $61(28-89)$ & $65(39-89)$ & 0.432 \\
\hline Male (\%) & 68.50 & 71.80 & 57.10 & 0.315 \\
\hline Pain-to-admission time (hours) & $2.00(1.50-2.50)$ & $2.00(1.50-2.50)$ & $2.00(1.60-2.60)$ & 0.783 \\
\hline \multicolumn{5}{|l|}{ Risk factors } \\
\hline Smoking (\%) & 39.10 & 45.10 & 19.00 & 0.058 \\
\hline Hypertension (\%) & 68.50 & 62.00 & 90.50 & 0.028 \\
\hline Hyperlipidaemia (\%) & 69.60 & 70.40 & 66.70 & 0.953 \\
\hline Diabetes mellitus (\%) & 31.50 & 26.80 & 47.60 & 0.124 \\
\hline \multicolumn{5}{|l|}{ History of CHD } \\
\hline Previous MI (\%) & 19.60 & 12.70 & 42.90 & 0.006 \\
\hline Previous PCI (\%) & 10.90 & 7.00 & 23.80 & 0.077 \\
\hline Previous CABG (\%) & 4.30 & 2.80 & 9.50 & 0.475 \\
\hline \multicolumn{5}{|c|}{$\begin{array}{l}\text { CHD - coronary heart disease; AMI - acute myocardial infarction; UA - unstable angina, PCI - percutaneous coronary intervention; CABG - corona } \\
\text { artery bypass grafting. } \\
\text { Age is presented as median (min-max) and pain-to-admission time as median (25th-75th percentiles). Differences between AMI and UA groups } \\
\text { were calculated with Mann-Whitney U test or Chi squarred test. }\end{array}$} \\
\hline
\end{tabular}


A

B

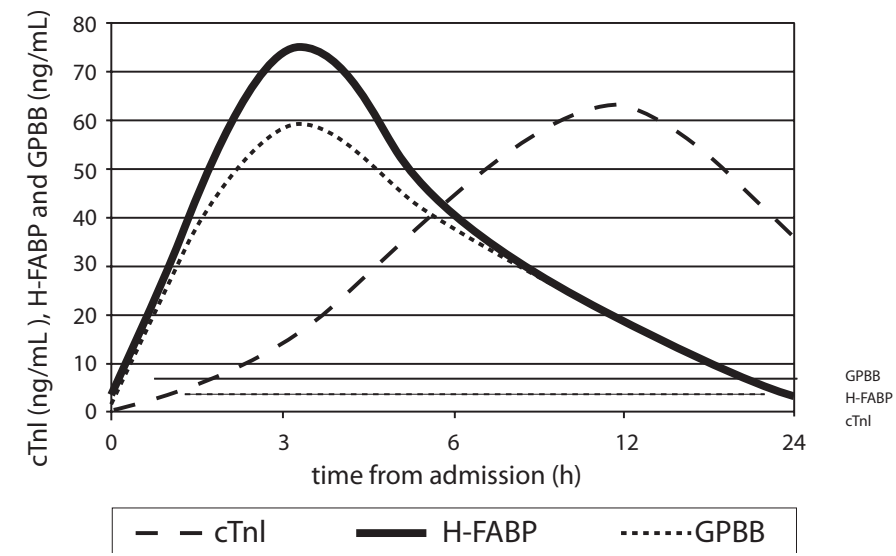

\begin{tabular}{|c|c|c|c|c|c|c|c|}
\hline \multirow[b]{2}{*}{$\begin{array}{l}\text { Time points } \\
\text { (hours) }\end{array}$} & \multirow[b]{2}{*}{$\begin{array}{l}\text { H-FABP } \\
(\mathrm{ng} / \mathrm{mL})\end{array}$} & \multirow[b]{2}{*}{$\begin{array}{c}\text { GPBB } \\
(\mathrm{ng} / \mathrm{mL})\end{array}$} & \multirow[b]{2}{*}{$\begin{array}{c}\text { cTnl } \\
(\mathrm{ng} / \mathrm{mL})\end{array}$} & \multirow[b]{2}{*}{$\mathbf{P}$} & \multicolumn{3}{|c|}{ Relative increase (\%) } \\
\hline & & & & & H-FABP & GPBB & cTnl \\
\hline 0 & $\begin{array}{c}3.33 \\
(1.10-11.01)\end{array}$ & $\begin{array}{c}5.30 \\
(2.10-13.50)\end{array}$ & $\begin{array}{c}0.08 \\
(0.02-0.20)\end{array}$ & $\begin{array}{l}\text { (a) } 0.254 \\
\text { (b) } 0.001 \\
\text { (c) } 0.001\end{array}$ & - & - & - \\
\hline 3 & $\begin{array}{c}73.54 \\
(38.2-110.9)\end{array}$ & $\begin{array}{c}58.30 \\
(30.2-122.5)\end{array}$ & $\begin{array}{c}13.79 \\
(3.76-49.09)\end{array}$ & $\begin{array}{l}\text { (a) } 0.788 \\
\text { (b) } 0.001 \\
\text { (c) } 0.001\end{array}$ & 2108.41 & 1000.00 & 17137.50 \\
\hline 6 & $\begin{array}{c}39.20 \\
(19.2-97.26)\end{array}$ & $\begin{array}{c}36.50 \\
(13.5-94.1)\end{array}$ & $\begin{array}{c}44.28 \\
(14.6-163.71)\end{array}$ & $\begin{array}{l}\text { (a) } 0.977 \\
\text { (b) } 0.003 \\
\text { (c) } 0.008\end{array}$ & 1077.18 & 588.68 & 55250.00 \\
\hline 12 & $\begin{array}{c}18.45 \\
(5.84-39.90)\end{array}$ & $\begin{array}{c}17.80 \\
(5.4-47.9)\end{array}$ & $\begin{array}{c}62.84 \\
(26.9-138.13)\end{array}$ & $\begin{array}{l}\text { (a) } 0.630 \\
\text { (b) } 0.001 \\
\text { (c) } 0.001\end{array}$ & 454.05 & 234.85 & 78450.00 \\
\hline 24 & $\begin{array}{c}3.93 \\
(1.40-10.27)\end{array}$ & $\begin{array}{c}2.70 \\
(2.0-6.5)\end{array}$ & $\begin{array}{c}36.20 \\
(17.35-69.3)\end{array}$ & $\begin{array}{l}\text { (a) } 0.306 \\
\text { (b) } 0.001 \\
\text { (c) } 0.001\end{array}$ & 18.02 & -49.06 & 45150.00 \\
\hline
\end{tabular}

Data are presented as median (25th-75th percentiles).

Figure 2. Average dynamics of $\mathrm{H}-\mathrm{FABP}, \mathrm{GPBB}$ and $\mathrm{cTnl}$ in patients with $\mathrm{AMI}(\mathrm{N}=71)$ admitted within 3 hours from symptom onset is shown graphically (A) and in the table (B). The statistical differences (P values) between H-FABP and GPBB (a); H-FABP and cTnl (b); GPBB and CTnl (c) are calculated with Wilcoxon test.

$B$ the level of statistical differences $(P)$ between $\mathrm{H}$ FABP and GPBB are designated as (a); between $\mathrm{H}$ FABP and cTnl are designated as (b) and between GPBB and cTnl are designated as (c). Shortly after admission, the concentrations of H-FABP and GPBB rapidly increased to equal levels, peaking at $3 \mathrm{~h}$ (73.54 (38.18-110.99) and 58.30 (30.20-122.50) ng/ $m L$, respectively) $(P(a)=0.788$, Figure $1 A$ and Figure 2, Table B). In contrast, the increase in cTnl concentration was slow during the same time period; at $3 \mathrm{~h}$, the cTnl levels were lower than those of $\mathrm{H}$ FABP and GPBB (P (b) and $(c)=0.001$, Figure $2 A$ and
Figure 2, Table B). However, rapid increase in cTnl concentrations was prominent at 6-12 $\mathrm{h}$ after admission, which was accompanied by a corresponding decrease in H-FABP and GPBB concentrations (Figure 2A). It resulted in significantly lower concentrations of both, H-FABP and GPBB when compared with cTnl at $6 \mathrm{~h}(\mathrm{P}(\mathrm{b})=0.003$ and $\mathrm{P}(\mathrm{c})=$ $0.008)$ and at $12 \mathrm{~h}$ after admission $(\mathrm{P}(\mathrm{b})$ and $(\mathrm{c})=$ 0.001 , Figure 2, Table B). The H-FABP and GPBB concentrations did not differ significantly between themselves at $6 \mathrm{~h}(\mathrm{P}(\mathrm{a})=0.97)$ and at $12 \mathrm{~h}(\mathrm{P}(\mathrm{a})=$ 0.630). At the 24 -h time point, the concentration of 
CTnl was higher than those of $\mathrm{H}-\mathrm{FABP}$ and GPBB ( $\mathrm{P}$ (b) and (c) $<0.001$ ), and H-FABP did not significantly differ from GPBB ( $P(a)=0.306$, Figure 2, Table $B)$.

Relative increase in $\mathrm{H}-\mathrm{FABP}$ in patients with $\mathrm{AMI}$ is particularly high at $3 \mathrm{~h}$ after admission and accounts for $2108.41 \%$ from the 0 -h time point (Figure 2, Table B). It decreased approximately 2 times at $6 \mathrm{~h}$ after admission and again doubly reduced at $12 \mathrm{~h}$ after admission (Figure 2, Table B). GPBB followed very similar dynamic, but the relative increase in GPBB was $1000 \%$ at $3 \mathrm{~h}$ after admission (Figure 2, Table B). At $3 \mathrm{~h}$ after admission relative increase in cTnl was $17137.50 \%$, it increased slowly, peaked at $12 \mathrm{~h}$ time point, when the relative increase was $78450.00 \%$. After that it slowly decreased at $24 \mathrm{~h}$ after admission. The concentrations of $\mathrm{H}-\mathrm{FABP}, \mathrm{GPBB}$ and $\mathrm{CTn}$ in patients with UA were always bellow their cut offs of $5.0 \mathrm{ng} / \mathrm{mL}, 7.0$ $\mathrm{ng} / \mathrm{mL}$ or $0.2 \mathrm{ng} / \mathrm{mL}$, respectively (Table 2 ).

\section{Receiver operating characteristic curves}

Table 2 shows the AUC for H-FABP and GPBB for the diagnosis of AMI. At admission, for patients having coronary chest pain for $<3 \mathrm{~h}$, the AUC was significantly greater for initial H-FABP $(0.91 ; 95 \% \mathrm{Cl}$ $=0.85-0.97$ and GPBB $(0.96 ; 95 \% \mathrm{Cl}=0.93-1.00$ in patients with $A M I$ than in patients with UA $(P<$ $0.001) ;$ this remained highly discriminatory for all the time points tested $(3,6,12$, and $24 \mathrm{~h}$ ) (Table 2 ). There appeared to be no difference between the $\mathrm{H}-\mathrm{FABP}$ and GPBB ROC curves.

\section{Diagnostic performance of H-FABP and GPBB}

In AMI patients, the sensitivities of H-FABP and GPBB at admission were rather low (37\% and 40\%, respectively) didn't differ significantly (Table 4). The sensitivity of H-FABP increased at 3 and $6 \mathrm{~h}$ after admission (99\% and $93 \%$, respectively), which was statistically similar to the sensitivity of GPBB. At the 24-h time point, the sensitivity of H-FABP decreased to $40 \%$; however, this was approximately 2 -times higher than the value for GPBB $(P<0.01)$ (Table 4). The specificity, positive- and negativepredictive values, positive and negative likelihood ratios, and risk ratios for $\mathrm{AMI}$ were calculated for both biomarkers (Table 3). The overall diagnostic accuracy of H-FABP and GPBB did not differ significantly.

TABLE 3. Area under receiver operating characteristic curves (AUC) for cardiac biomarkers at the optimal cut off points $\left(99^{\text {th }}\right.$ percentile of the general population) for the diagnosis AMI in patients admitted within 3 hours from symptom onset $(\mathrm{N}=71)$ in respect to patients with unstable angina $(\mathrm{N}=21)$.

\begin{tabular}{lcccc}
\hline Biomarker & $\begin{array}{c}\text { Time points } \\
\text { (hours) }\end{array}$ & AUC & 95\% CI & P \\
\hline & 0 & 0.91 & $0.85-0.97$ & $<0.001$ \\
& 3 & 0.97 & $0.92-1.02$ & $<0.001$ \\
H-FABP & 6 & 0.96 & $0.89-1.03$ & $<0.001$ \\
& 12 & 0.98 & $0.96-1.00$ & $<0.001$ \\
& 24 & 0.92 & $0.86-0.98$ & $<0.001$ \\
\hline & 0 & 0.96 & $0.93-1.00$ & $<0.001$ \\
& 3 & 0.93 & $0.86-0.99$ & $<0.001$ \\
GPBB & 6 & 0.90 & $0.81-0.98$ & $<0.001$ \\
& 12 & 0.92 & $0.85-0.98$ & $<0.001$ \\
& 24 & 0.90 & $0.84-0.97$ & $<0.001$ \\
\hline Cl-confidence intervals. & & & \\
\hline
\end{tabular}

TABLE 2. Average dynamics of $H-F A B P, G P B B$ and $c T n l$ in patients with UA ( $N=21$ ) admitted within 3 hours from symptom onset.

\begin{tabular}{lccccc}
\hline & \multicolumn{5}{c}{ Time points (hours) } \\
& $\mathbf{0}$ & $\mathbf{3}$ & $\mathbf{6}$ & $\mathbf{1 2}$ & $\mathbf{2 4}$ \\
\hline $\mathbf{H - F A B P}$ & 0.34 & 0.4 & 0.6 & 0.1 & 0.1 \\
(ng/mL) & $(0.1-0.71)$ & $(0.15-1.71)$ & $(0.1-1.4)$ & $(0-0.38)$ & $(0-0.35)$ \\
GPBB & 0.2 & 1.2 & 2,1 & 1.23 & 0.9 \\
(ng/mL) & $(0-1.55)$ & $(0.2-4.05)$ & $(0.45-4.27)$ & $(0.95-2.05)$ & $(0-1.65)$ \\
$\mathbf{c T n l}$ & 0.02 & 0.02 & 0.01 & 0.01 & 0 \\
(ng/mL) & $(0-0.02)$ & $(0-0.02)$ & $(0.01-0.1)$ & $(0-0.02)$ & $(0-0.01)$ \\
\hline
\end{tabular}

Data are presented as median (25th-75th percentiles). 
TABLE 4. Significance of diagnostic H-FABP and GPBB estimation in patients with AMI admitted within 3 hours from symptom onset $(\mathrm{N}=71)$.

\begin{tabular}{|c|c|c|c|c|c|}
\hline & & & $\begin{array}{l}\text { Time points } \\
\text { (hours) }\end{array}$ & & \\
\hline & 0 & 3 & 6 & 12 & 24 \\
\hline & \multicolumn{5}{|c|}{ H-FABP } \\
\hline Sensitivity & $\begin{array}{c}37 \% \\
(27-49 \%)\end{array}$ & $\begin{array}{c}99 \% \\
(92-100 \%)\end{array}$ & $\begin{array}{c}93 \% \\
(85-97 \%)\end{array}$ & $\begin{array}{c}77 \% \\
(66-85 \%)\end{array}$ & $\begin{array}{c}40 \% \\
(29-52 \%)\end{array}$ \\
\hline Specificity & $\begin{array}{c}96 \% \\
(78-99 \%)\end{array}$ & $\begin{array}{c}91 \% \\
(71-98 \%)\end{array}$ & $\begin{array}{c}95 \% \\
(77-99 \%)\end{array}$ & $\begin{array}{c}96 \% \\
(78-99 \%)\end{array}$ & $\begin{array}{c}96 \% \\
(78-99 \%)\end{array}$ \\
\hline Positive predictive value & $\begin{array}{c}96 \% \\
(82-99 \%)\end{array}$ & $\begin{array}{c}97 \% \\
(90-99 \%)\end{array}$ & $\begin{array}{c}99 \% \\
(92-100 \%)\end{array}$ & $\begin{array}{c}98 \% \\
(90-100 \%)\end{array}$ & $\begin{array}{c}97 \% \\
(83-99 \%)\end{array}$ \\
\hline Negative predictive value & $\begin{array}{c}32 \% \\
(22-44 \%)\end{array}$ & $\begin{array}{c}95 \% \\
(76-99 \%)\end{array}$ & $\begin{array}{c}80 \% \\
(61-91 \%)\end{array}$ & $\begin{array}{c}57 \% \\
(41-71 \%)\end{array}$ & $\begin{array}{c}33 \% \\
(23-46 \%)\end{array}$ \\
\hline Positive likelihood ratio & $\begin{array}{c}8.17 \\
(1.2-56.8)\end{array}$ & $\begin{array}{c}10.35 \\
(2.77-38.70)\end{array}$ & $\begin{array}{c}19.52 \\
(2.88-132.33)\end{array}$ & $\begin{array}{c}16.97 \\
(2.49-115.66)\end{array}$ & $\begin{array}{c}8.80 \\
(1.27-61.01)\end{array}$ \\
\hline Negative likelihood ratio & $\begin{array}{c}0.66 \\
(0.54-0.81)\end{array}$ & $\begin{array}{c}0.02 \\
(0.00-0.11)\end{array}$ & $\begin{array}{c}0.07 \\
(0.03-0.17)\end{array}$ & $\begin{array}{c}0.24 \\
(0.15-0.37)\end{array}$ & $\begin{array}{c}0.63 \\
(0.51-0.78)\end{array}$ \\
\hline \multirow[t]{2}{*}{ Risk ratio } & $\begin{array}{c}1.48 \\
(1.25-1.75) \\
\end{array}$ & $\begin{array}{c}19.44 \\
(2.88-131.41) \\
\end{array}$ & $\begin{array}{c}4.93 \\
(2.25-10.79) \\
\end{array}$ & $\begin{array}{c}2.32 \\
(1.60-3.35) \\
\end{array}$ & $\begin{array}{c}1.50 \\
(1.26-1.79) \\
\end{array}$ \\
\hline & \multicolumn{5}{|c|}{ GPBB } \\
\hline Sensitivity & $\begin{array}{c}40 \% \\
(29-52 \%)\end{array}$ & $\begin{array}{c}97 \% \\
(90-99 \%)\end{array}$ & $\begin{array}{c}86 \% \\
(76-92 \%)\end{array}$ & $\begin{array}{c}70 \% \\
(59-80 \%)\end{array}$ & $\begin{array}{c}23 \% \\
(15-34 \%)^{*}\end{array}$ \\
\hline Specificity & $\begin{array}{c}96 \% \\
(78-99 \%)\end{array}$ & $\begin{array}{c}81 \% \\
(60-92 \%)\end{array}$ & $\begin{array}{c}86 \% \\
(65-95 \%)\end{array}$ & $\begin{array}{c}95 \% \\
(77-99 \%)\end{array}$ & $\begin{array}{c}96 \% \\
(78-99 \%)\end{array}$ \\
\hline Positive predictive value & $\begin{array}{c}97 \% \\
(83-99 \%)\end{array}$ & $\begin{array}{c}95 \% \\
(87-98 \%)\end{array}$ & $\begin{array}{c}95 \% \\
(87-98 \%)\end{array}$ & $\begin{array}{c}98 \% \\
(90-100 \%)\end{array}$ & $\begin{array}{c}94 \% \\
(73-99 \%)\end{array}$ \\
\hline Negative predictive value & $\begin{array}{c}33 \% \\
(23-46 \%)\end{array}$ & $\begin{array}{c}90 \% \\
(69-97 \%)\end{array}$ & $\begin{array}{c}64 \% \\
(46-79 \%)\end{array}$ & $\begin{array}{c}49 \% \\
(34-64 \%)\end{array}$ & $\begin{array}{c}28 \% \\
(19-39 \%)\end{array}$ \\
\hline Positive likelihood ratio & $\begin{array}{c}8.80 \\
(1.27-61.01)\end{array}$ & $\begin{array}{c}5.10 \\
(2.11-12.33)\end{array}$ & $\begin{array}{c}6.01 \\
(2.10-17.22)\end{array}$ & $\begin{array}{c}14.79 \\
(2.17-100.74)\end{array}$ & $\begin{array}{c}5.03 \\
(0.71-35.80)\end{array}$ \\
\hline Negative likelihood ratio & $\begin{array}{c}0.63 \\
(0.51-0.78)\end{array}$ & $\begin{array}{c}0.04 \\
(0.01-0.14)\end{array}$ & $\begin{array}{c}0.16 \\
(0.09-0.03)\end{array}$ & $\begin{array}{c}0.31 \\
(0.21-0.45)\end{array}$ & $\begin{array}{c}0.81 \\
(0.69-0.95)\end{array}$ \\
\hline Risk ratio & $\begin{array}{c}1.50 \\
(1.26-1.79) \\
\end{array}$ & $\begin{array}{c}8.98 \\
(2.42-33.35) \\
\end{array}$ & $\begin{array}{c}2.67 \\
(1.62-4.40) \\
\end{array}$ & $\begin{array}{c}1.91 \\
(1.42-2.59) \\
\end{array}$ & $\begin{array}{c}1.39 \\
(1.21-1.60) \\
\end{array}$ \\
\hline
\end{tabular}

Level of statistical significance ${ }^{*} \mathrm{P}<0.01$ between sensitivity of H-FABP and GPBB at 24 hours after the admission as calculated with Z-test. Values in parentheses represent $95 \%$ confidence intervals; $h$, hours after admission.

\section{Discussion}

The ability to distinguish acute ACS patients from a very large proportion of patients with cardiac pain is a diagnostic challenge, especially for patients with no clear symptoms, unclear ECG features, and/or borderline diagnostic cTnl concentrations (1). Elderly women who have survived a myocardial infarction frequently visit their doctors complaining of chest pain and have significantly higher mortality rate, target lesion reoclussion $(3,24)$, postinfarction refractory anaemia in the short term, and AMI in the long term $(25,26)$. Although cardiac troponin is a pivotal marker of cardiac ischaemic injury/necrosis (27), a single negative cTnl test is not sufficient to disregard the presence of AMI because of its low sensitivity in the first $3 \mathrm{~h}$ of chest pain onset $(2,3)$. Our results 
showing a slow, early increase in cTnl concentrations to above the cut-off value at the time of early patient admission also suggest this. Therefore, repeated measurements of cTnl concentrations in the period of its higher sensitivity (84.1\%) and specificity (93.4\%) (28) are required, which comprises the subsequent 6-9 $\mathrm{h}$ after admission $(27,28)$. Accordingly, we noticed a rapid increase in cTnl concentrations between 6 and $12 \mathrm{~h}$ after admission. This substantially prolongs the time required for an accurate diagnosis after the acute coronary event and reduces the likelihood of achieving high-quality myocardial revascularization by primary percutaneous intervention or stent implantation $(25,29)$. Recently introduced highsensitivity troponin assays are capable of identifying high-risk patients early and more effectively, providing a reliable and rapid prognosis prediction that enables a fast-track rule-out protocol (3 h) $(1,7)$. However, higher-sensitivity cardiac troponin assays rather reflect the troponin release after increased permeability of the myocardial cell membrane without specifically pointing out necrosis, which is a characteristic feature of a clinically threatening AMI (8). Although cTnT concentrations, measured using high-sensitivity assays, are elevated early after the acute coronary event, its diagnostic accuracy may be compromised because levels can also be elevated in many patients with stable angina $(30,31)$ and in healthy individuals (32), thus weakening its ability to differentiate between healthy subjects and patients with AMI, $U A$, and stable angina. According to the sensitivity of the ELISAs used in our study, both H-FABP and GPBB markers were not elevated in the patients with UA, which is in contrast to that in patients with $\mathrm{AMI}$, and statistically significant differences were obtained from AUC analysis at all time points tested. This emphasizes the significance of $\mathrm{H}$-FABP and GPBB in distinguishing UA from AMI, particularly during early ACS with peak sensitivities and specificities occurring at $3 \mathrm{~h}$ after admission. This is in contrast to other studies, which suggest that $\mathrm{H}$ FABP might be a marker for myocardial ischaemia even in the absence of necrosis (10). Recently, $\mathrm{H}$ FABP has been proposed to be an early marker for ACS because it is only elevated in AMI patients
$(4,10,17)$ and appears before the traditional marker troponin in $22 \%$ patients at presentation (3). Wiswanathan et al. (10) confirmed the prognostic value and independent prediction of death by using elevated H-FABP levels in low- and intermediate-risk patients with suspected ACS. We advocate the use of H-FABP alone or in combination with high-sensitivity troponin assays to improve the sensitivity of early AMI diagnosis. This is in agreement with the opinion of McCann et al. who declared that assessment of H-FABP within the first 4 $h$ of symptom onset is even superior to cTnT for the detection of AMI (14). Our results show that GPBB has very similar average dynamics to $H-F A B P$, as reported previously (15). GPBB does not compete with cTnT in terms of sensitivity in AMI patients (14), especially at the first hour after admission (33). Its activation in myocardial ischaemia is a result of an increased glycogen degradation, which results in GPBB release into the bloodstream $(15,22)$ and diminishes its diagnostic accuracy to distinguish between AMI and UA (33). However, its specificity is high and comparable to that of CK-MB (15). All humoral biomarkers have been criticized in terms of their specificity. Accordingly, troponin concentrations may be increased in patients with serious vascular chest pain, non-coronary myocardial injury, skeletal myopathies, or chronic renal failure, resulting in incorrect prognosis $(1,8)$. $\mathrm{H}$ FABP was also criticized for insufficient specificity, owing to its presence in different tissues such as the skeletal muscles, liver, adipose tissue, gut, skin, kidney, or brain (14). The specificity of H-FABP can be improved using modern assays with no crossreactivity (12) and particularly in combination with high-sensitivity cTnT assay. GPBB isoforms are present in the brain, muscle, and liver, with approximately $80 \%$ similarity between the muscle and liver (15). The brain isoform is substantially different and can be distinguished with an appropriate sensitive immunoassay method (15). However, the magnitude of fluctuation, depending on the initial concentration and clinical symptoms, is increasingly important to differentiate between acute or chronic myocardial damage, which has been reported recently for cTnl (6); however, the levels from baseline are still debated $(1,2)$. The results 
presented in this study show statistically significant changes in the concentrations of H-FABP and GPBB as compared to their initial values (relative increase) at $3 \mathrm{~h}$ after the admission of AMI patients. This highlights the importance of $\mathrm{H}$-FABP and GPBB for the early diagnosis of AMI. However, the sensitivities of H-FABP and GPBB in patients with AMI were relatively low at admission (approximately $40 \%$ for both markers), similarly to that showed during the first hours after admission (33). However, they concomitantly increased, peaking at $3 \mathrm{~h}$, before gradually decreasing by $20-40 \%$ at $24 \mathrm{~h}$. This emphasizes the rapidly changing dynamics of H-FABP and GPBB, owing to the narrow time period of their peak concentrations, relative increases and sensitivities, which highlights the importance of analyzing their concentrations throughout the first $24 \mathrm{~h}$ of AMI onset. At $24 \mathrm{~h}$, the sensitivity of GPBB was almost twice lower that of $\mathrm{H}-\mathrm{FABP}$, according the results shown herewith. Furthermore, GPBB has approximately twice lower relative increase then $\mathrm{H}-\mathrm{FABP}$ during the first 24 hours after admission in patients having coronary

\section{References}

1. Hamm CW, Bassand JP, Agewall S, Bax J, Boersma E, Bueno $H$, et al. ESC Guidelines for the management of acute coronary syndromes in patients presenting without persistent ST-segment elevation: The Task Force for the management of acute coronary syndromes (ACS) in patients presenting without persistent ST-segment elevation of the European Society of Cardiology (ESC). Eur Heart J 2011:32;2999-3054.

2. Thygesen K, Alpert JS, White HD, on behalf of the Joint ESC/ ACCF/AHA/WHF Task Force for the Redefinition of Myocardial Infarction. Universal definition of myocardial infarction. Eur Heart J 2007;28:2525-38.

3. Moe KT, Wong P. Current trends in diagnostic biomarkers of acute coronary syndrome. Ann Acad Med Singapore 2010;39:210-5.

4. Okamoto F, Sohmiya K, Ohkaru Y, et al. Human heart-type cytoplasmic fatty acid-binding protein (H-FABP) for the diagnosis of acute myocardial infarction. Clinical evaluation of H-FABP in comparison with myoglobin and creatine kinase isoenzyme MB. Clin Chem Lab Med 2000;38:231-8.

5. Panteghini M, Pagani F, Bonetti G. The sensitivity of cardiac markers: an evidence-based approach. Clin Chem Lab Med 1999;37:1097-106. chest pain for $<3 \mathrm{~h}$, what one should keep in mind during the diagnosis of AMI. In our opinion there is no major benefit to the simultaneous use of $\mathrm{H}$ FABP and GPBB because of their quite similar diagnostic accuracy up to the 24-h time point and because of the cost of such combined diagnostic approach.

In conclusion, our results show that $\mathrm{H}-\mathrm{FABP}$ and GPBB can improve the early detection of AMI, with a high diagnostic accuracy. These biomarkers are especially useful for distinguishing between AMI and UA within $3 \mathrm{~h}$ after admission in patients with chest pain for $<3$ hours, which is the time period during which an emergency physician should plan an objective cardiac ischaemia evaluation and appropriate therapy.

\section{Acknowledgements}

This work was supported by the grant of Croatian Ministry of Science No. 062-1081875-0545.

\section{Potential conflict of interest}

None declared.

6. Introcaso G, Raggi M, D'Errico T, Cavallero A. Short-term increases of plasma cardiac troponin I are better evaluated by comparison with the reference change value. Biochem Med 2010;20:327-33.

7. Aldous SJ, Richards M, Cullen L, Troughton R, Than M. Diagnostic and prognostic utility of early measurement with high-sensitivity troponin $T$ assay in patients presenting with chest pain. 2012:184;E260-8.

8. Lippi G, Cervelin G, Banfi G, Plebani M. Cardiac troponins and physical exercise. It's time to make a point. Biochem Med 2011;21:55-62.

9. Steg PG, FitzGerald G, Fox KA. Risk stratification in non-STsegment elevation acute coronary syndromes: troponin alone is not enough. Am J Med 2009;122:107-8.

10. Viswanathan K, Kilcullen N, Morrell C, Thistlethwaite SJ, Sivananthan MU, Hassan TB, et al. Heart-type fatty acid-binding protein predicts long-term mortality and re-infarction in consecutive patients with suspected acute coronary syndrome who are troponin-negative. J Am Coll Cardiol 2010;55:2590-8. 
11. Gururajan $P$, Gurumurthy $P$, Nayar $P$, Srinivasa Nageswara Rao G, Babu S, Cherian KM. Heart fatty acid binding protein (H-FABP) as a diagnostic biomarker in patients with acute coronary syndrome. Heart Lung Circ 2010;19:660-4.

12. Alhadi HA, Fox KA. Do we need additional markers of myocyte necrosis: the potential value of heart fatty-acid-binding protein. QJM 2004;97:187-98.

13. Pelsers MM, Hermens WT, Glatz JF. Fatty acid-binding proteins as plasma markers of tissue injury. Clin Chim Acta 2005;352:15-35.

14. McCann CJ, Glover BM, Menown IBA, Moore MJ, McEneny $J$, Owens CG, et al. Novel biomarkers in early diagnosis of acute myocardial infarction compared with cardiac troponin T. Eur Heart J 2008;29: 2843-50.

15. Rabitzsch G, Mair J, Lechleitner P, Noll F, Hofmann U, Krause $E G$, et al. Immunoenzymometric assay of human glycogen phosphorylase isoenzyme $B B$ in diagnosis of ischemic myocardial injury. Clin Chem 1995;41:966-78.

16. Mair J. Glycogen phosphorylase isoenzyme BB to diagnose ischaemic myocardial damage. Clin Chim Acta 1998;272: 79-86.

17. Seino $Y$, Ogata K, Takano $T$, Ishii J, Hishida $H$, Morita $H$, et al. Use of a whole blood rapid panel test for heart-type fatty acid-binding protein in patients with acute chest pain: comparison with rapid troponin T and myoglobin tests. Am J Med 2003;115:185-90.

18. Graham I, Atar D, Borch-Johnsen K, Boysen G, Burell G, Cifkova $R$, et al. European guidelines on cardiovascular disease prevention in clinical practice: full text. Fourth Joint Task Force of the European Society of Cardiology and other societies on cardiovascular disease prevention in clinical practice (constituted by representatives of nine societies and by invited experts). Eur J Cardiovasc Prev Rehabil 2007;Suppl 2:S1-113.

19. American Diabetes Association. Diagnosis and classification of diabetes mellitus. Diabetes Care 2010;33:562-9.

20. Hafner $G$, Peetz D, Erbes $H$, Post F, Dahm M, Peivandi AA, et al. Comparison of diagnostic performance of cardiac troponin I on the IMMULITE system with other automated assays in minor myocardial damage. Scand J Clin Lab Invest 2001;61:227-35.

21. Morariu AM, Loef BG, Aarts $L P$, Rietman GW, Rakhorst G, van Oeveren $W$, et al. Dexamethasone: benefit and prejudice for patients undergoing on-pump coronary artery bypass grafting: a study on myocardial, pulmonary, renal, intestinal, and hepatic injury. Chest 2005; 128:2677-87.
22. Peetz $D$, Post $F$, Schinzel $H$, Schweigert $R$, Schollmayer $C$ Steinbach $K$, et al. Glycogen phosphorylase BB in acute coronary syndromes. Clin Chem Lab Med 2005;43:1351-8.

23. Dupont WD, Plummer WD. Power and Sample Size Calculations for Studies Involving Linear Regression. Control Clin Trials 1998;19:589-601.

24. Kawecki D, Tomasik AR, Morawiec B, Jachec W, Wojciechowska $C$, Rybczyk R, et al. Analysis of myocardial infarction time course in women compared with men in Upper Silesia population in 30 day follow-up. Int Heart J 2009;50:71121.

25. Hoenig MR, Aroney CN, Scott IA. Early invasive versus conservative strategies for unstable angina and non-ST elevation myocardial infarction in the stent era. Cochrane Database Syst Rev 2010;3:CD004815.

26. Manari A, Albiero R, De Servi S. High-risk non-ST-segment elevation myocardial infarction versus ST-segment elevation myocardial infarction: same behaviour and outcome? J Cardiovasc Med 2009;10 Suppl 1:S13-6.

27. Thygesen K, Mair J, Katus H, Plebani M, Venge P, Collinson $P$, et al. Recommendations for the use of cardiac troponin measurement in acute cardiac care. Eur Heart J 2010;31:2197204.

28. Diercks DB, Peacock WF 4th, Hollander JE, Singer AJ, Birkhahn $R$, Shapiro $N$, et al. Diagnostic accuracy of a pointof-care assay for acute myocardial infarction within 3 hours after presentation in early presenters to the emergency department with chest pain. Am J 2012;163:74-80.

29. Serruys PW, Morice MC, Kappetein AP, Colombo A, Holmes $D R$, Mack MJ, et al. Percutaneous coronary intervention versus coronary-artery bypass grafting for severe coronary artery disease. N Engl J Med 2009;360:961-72.

30. Omland $T$, de Lemos JA, Sabatine MS, Christophi CA, Rice MM, Jablonski $K A$, et al. A sensitive cardiac troponin T assay in stable coronary artery disease. N Engl J Med 2009;361:2538-47.

31. de Lemos JA, Drazner MH, Omland T, Ayers CR, Khera A, Rohatgi $A$, et al. Association of troponin T detected with a highly sensitive assay and cardiac structure and mortality risk in the general population. JAMA 2010;304:2503-12.

32. Otsuka T, Kawada T, Ibuki C, Seino Y. Association between high-sensitivity cardiac troponin T levels and the predicted cardiovascular risk in middle-aged men without overt cardiovascular disease. Am Heart J 2010;159:972-8.

33. Bozkurt S, Kaya EB, Okutucu S, Aytemir K, Coskun F, Oto A. The diagnostic and prognostic value of first hour glycogen phosphorylase isoenzyme BB level in acute coronary syndrome. Cardiol J 2011;18:496-502. 


\section{Dijagnostička točnost srčanog proteina koji veže masne kiseline (H-FABP) i BB izoenzima glikogen-fosforilaze (GPBB) u u postavljanju dijagnoze akutnog infarkta miokarda kod bolesnika s akutnim koronarnim sindromom}

\section{Sažetak}

Uvod: Cilj ovog istraživanja je procijeniti mogu li se srčani protein koji veže masne kiseline (engl. heart fatty acid-binding protein, H-FABP) i BB izoenzim glikogen-fosforilaze (engl. glycogen phosphorylase isoenzyme BB, GPBB) rabiti za točno dijagnosticiranje akutnog infarkta miokarda (engl. acute myocardial infarction, AMI) kod bolesnika s akutnim koronarnim sindromom (engl. acute coronary syndrome, ACS).

Materijali i metode: U istraživanje je bilo uključeno 108 bolesnika s ACS primljenih na kardiološki odjel unutar 3 sata od pojave boli u prsima. Klasičnom metodom za određivanje koncentracije srčanog troponina I (cTnl) odvojili smo bolesnike s AMI i one s nestabilnom anginom (engl. unstabile angina, UA). Koncentracije H-FABP i GPBB određene su ELISA metodom pri prijemu (0 h) i 3, 6, 12 te 24 sati nakon prijema na odjel; njihova točnost kod postavljanja dijagnoze AMI procijenjena je statističkim metodama.

Rezultati: Od 92 bolesnika s ACS, 71 je imao AMI. Vršne vrijednosti koncentracija H-FABP i GPBB 3 sata nakon prijema bile su više od onih cTnl (P $=0,001)$. Nakon 24 sata oba su se biljega normalizirala. Područje ispod ROC krivulje bilo je značajno veće za oba biljega kod bolesnika s AMI nego kod bolesnika s UA u svim trenucima testiranja, uključujući i vrijeme prijema ( $\mathrm{P}<0,001)$. Kod prijema su osjetljivost za H-FABP (37\%) i za GPBB (40\%) bile relativno niske. Porasle su $3 \mathrm{i} 6$ sati nakon prijema za oba biljega, a nakon 24h su ponovno pale te iznosile 40\% za H-FABP i približno 2 puta niže za GPBB $(P<0,01)$. Kod bolesnika s AMI oba su biološka biljega imala slične specifičnosti, pozitivne i negativne prediktivne vrijednosti, pozitivne i negativne omjere vjerojatnosti te omjere rizika za AMI.

Zaključak: Određivanje koncentracije H-FABP i GPBB može doprinijeti ranom dijagnosticiranju AMI te se može rabiti za razlikovanje AMI od UA. Ključne riječi: biološki biljezi; srčani protein koji veže masne kiseline; glikogen-fosforilaza; osjetljivost; specifičnost; akutni infarkt miokarda 